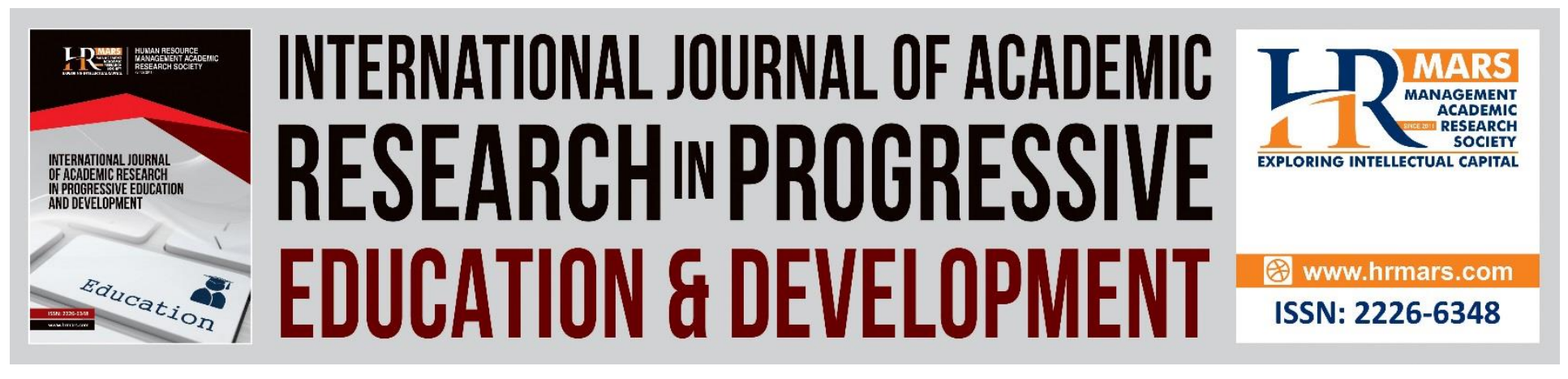

\title{
The Perspectives of Parents Toward the Practices of Pre- School Ethos During Routine Activities in Perpaduan (Unity) Pre-School Settings
}

Nordin Mamat, Loy Chee Luen, Mazlina Che Mustafa, Abdul Rahim Razalli, Abdul Rahim Hamdan \& Abdul Talib M. Hashim

To Link this Article: http://dx.doi.org/10.6007/IJARPED/v10-i1/8030

DOI:10.6007/IJARPED/v10-i1/8030

Received: 01 December 2020, Revised: 26 January 2021, Accepted: 12 February 2021

Published Online: 28 February 2021

In-Text Citation: (Mamat et al., 2021)

To Cite this Article: Mamat, N., Luen, L. C., Mustafa, M. C., Razalli, A. R., Hamdan, A. R., \& Hashim, A. T. M.

(2021). The Perspectives of Parents Toward the Practices of Pre-School Ethos During Routine Activities in

Perpaduan (Unity) Pre-School Settings. International Journal of Academic Research in Progressive Education and Development, 10(1), 187-194.

Copyright: (C) 2021 The Author(s)

Published by Human Resource Management Academic Research Society (www.hrmars.com)

This article is published under the Creative Commons Attribution (CC BY 4.0) license. Anyone may reproduce, distribute, translate and create derivative works of this article (for both commercial and non-commercial purposes), subject to full attribution to the original publication and authors. The full terms of this license may be seen at: http://creativecommons.org/licences/by/4.0/legalcode

Vol. 10(1) 2021, Pg. 187 - 194

http://hrmars.com/index.php/pages/detail/IJARPED JOURNAL HOMEPAGE

Full Terms \& Conditions of access and use can be found at http://hrmars.com/index.php/pages/detail/publication-ethics 


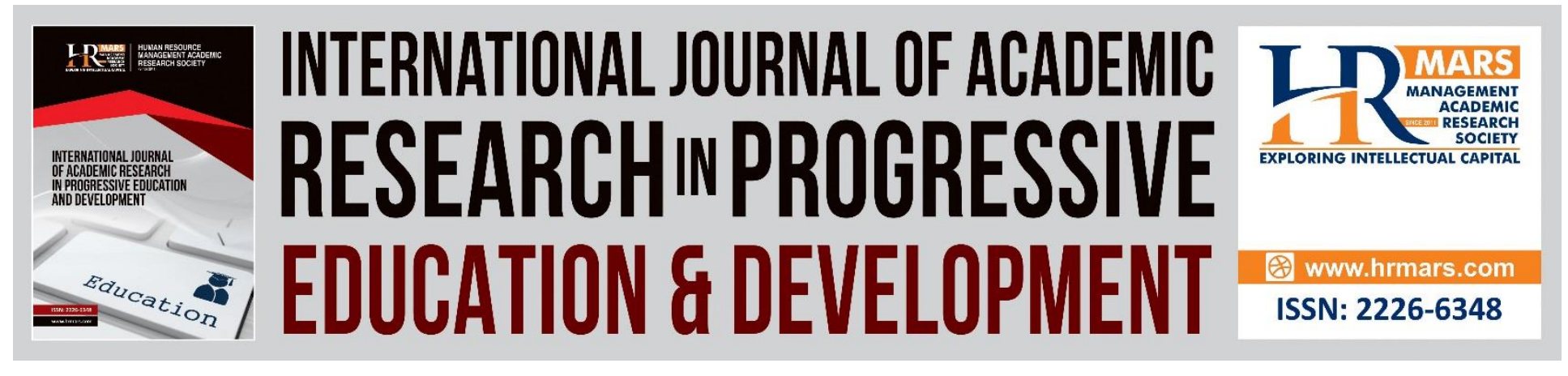

\title{
The Perspectives of Parents Toward the Practices of Pre-School Ethos During Routine Activities in Perpaduan (Unity) Pre-School Settings
}

\author{
Nordin Mamat, Loy Chee Luen, Mazlina Che Mustafa, Abdul \\ Rahim Razalli, Abdul Rahim Hamdan \& Abdul Talib M. Hashim \\ Faculty of Human Development, Universiti Pendidikan Sultan Idris, Malaysia.
}

\begin{abstract}
The objective of this study to investigate the views of parents toward the practice of pre-school ethos on routines activities in PERPADUAN (Unity) Pre-school settings. The study involved 30 parents from three PERPADUAN Pre-school settings. A qualitative methodology was applied. Indepth interviews were conducted with the parents. The primary findings of this case study emergent: the data and quotes from parents shown an important view of a pre-school ethos that claims to be multi-ethnic. There are the similarities and differences between pre-school ethos in line with the parental norms and values from parents' perspectives. For example, daily practices in the PERPADUAN Pre-school were acceptable. The common routine activities in pre-school day consist of the arrival time, morning assembly, hand-kissing, the salaam, the Rukun Negara (Malaysia Principle) and Negaraku (Malaysia Anthem), outdoor activity, and table manners during meal time. However, despite a good practices of multi-ethnic values through pre-school routines like "dua" and kissing hands, some of the findings evidently suggest that there are some lively 'sensitive issues'. Most of the issues commented on by the parents are related to the school's reluctance to act in a culturally sensitive way. Reciting "dua" is an act highly encouraged in Islam, regardless of time and place, but in a multi-ethnic pre-school like PERPADUAN Preschool this ritual is 'over emphasised' and regarded as 'compulsory', so that everybody must follow it regardless of their religion, even though the "dua" is recited in Malay. Some might think that this is an act of the Islamisation of pre-school and this might worry them.
\end{abstract}

Keywords: Pre-school, Ethos, Routine, Early Childhood

\section{Introduction}

This paper draws on a study that is part of a longitudinal research project that analyses Quality of Early Childhood Care and Education in formal early years settings with 4 -6-year-old children in Malaysia. The efforts to maintain the atmosphere of a peaceful and harmonious life among the various multi-ethnics in Malaysia is not an easy one. The establishment of multi-ethnic preschools are playing an important role in the integration of people since the early ages. The 
strength of multi-ethnic pre-school is a role in inculcating the spirit of goodwill, neighbourliness and integration among children in early childhood. In addition, the role multi-ethnic pre-school strengthen ties and foster unity among parents and the community. Generally, multi-ethnic preschool is a link between children, parents or guardians and the community. Multi-ethnic preschool implemented to provide children aged four to six years to appreciate the values from multi-ethnic groups and social life.

The roles and responsibilities of multi-ethnic pre-school such as PERPADUAN pre-school must be clear so that it can discharge their functions efficiently. In order to achieve the vision, mission and objectives multi-ethnic preschool, education is one of the strategy in the process to achieve national unity and integration. However the lack of delegating tasks that are unclear over workload will affect the quality of educational services provided. The questions is, does the educational services provided and practices quality enough? According to Buchori and Dobinson (2015) early childhood teachers view the children's previous cultural background as a burden. They are concern for the children who are not performing up to the curriculum standard and fear of not meeting their own expectations, and those of the children's parents. Meanwhile Mamat et al (2019) added that in Malaysia, early childhood education, in order to address the needs of the children from a diverse cultural background, the government agency such as Department of Integration and Unity implemented a setting of a culturally diverse pre-school. This shows the government' understandings of the multi-ethnic education goals. It is important to teach children about different cultures and the most effective way to do this is to emphasise points of comparison between cultures.

\section{Objectives}

The rationale for this study is to provide relevant input to the efforts of fulfil parents' expectation. The objective of study:

- to investigate the views of parents toward the practice of pre-school ethos on routines activities in PERPADUAN (Unity) Pre-school.

\section{Literature Review}

Multi-ethnic pre-school refers to "pre-school that includes children of different ethnic groups, which is the policy of the pre-school itself to ensure the composition of the pre-school entrants consist of a mix of Malays, Chinese, Indian and others. The aim of the multi-ethnic pre-school is to unite three dominant ethnic groups of Malaysian in order to ensure national integration" (Majzub, 2006, p. 87). Many scholars have addressed the benefits of pre-school settings for children's attention during learning activities. Pre-school setting promotes children's attention and learning at an early stage. Children's participation in classroom activities is highly influenced by pre-school setting and teacher's approach. According to Mamat et al (2019) direct cross-ethnic and teaching is more effective in changing children's intergroup attitudes. Studies show healthy and conducive environment of multi-ethnic pre-school give effective educational programs for children. Teachers always worked in a conducive working environment is committed to achieving the mission and goals to promote unity (Majzub, 2006). The involvement of parents and 
communities in PERPADUAN pre-school enhance relationships and joint activity, the cooperation between them (Majzub, 2006).

Learning activities in PERPADUAN pre-school should be based on the needs, desires, abilities of the children's background and development. Teachers should provide an activity space, organize physical needs in the classroom to carry out learning activities. Pre-schools need to provide activity and teaching planning appropriate to children (Beaty, 2014; 2016; Loy et al., 2017; Mamat et al., 2017). Previous studies show that the quality of pre-school is determined by the best practices in pre-school ethos such as curriculum, the profile of children, quality of the teacher, facilities, and teaching and learning practices. Bentley (2012) explains the meaning of diversify ethnically pre-school in the early childhood classroom practices in the everyday lives of four- and five-year-olds. According to Mamat et al (2019), the practice of multi-ethnic teaching in early childhood education is an important element of high-quality developmentally and culturally appropriate early childhood programmes. Children develop their own concepts around these issues, finding meaningful ways to share their knowledge with the larger school community. These fundamental values can be integrated into the lives of young children, especially in the early childhood classroom.

\section{Methodology}

This study is a qualitative study involving three PERPADUAN (Unity) Pre-school settings that conduct early education programs for pre-school children aged 6 . The study involved 30 parents from three PERPADUAN (Unity) Pre-school settings. In-depth interviews were conducted with the parents. The research employed interviews to serve as data collection instruments as well as means of data triangulation; to estimate the validity and reliability of data and research procedures (Mamat, et al., 2018). A series of workshops were carried out to construct the interview protocols. A series of workshops were held to thrash out the nodes, axial nodes and the systematic nodes. Relationships between the axial nodes were scrutinised to narrow them down into major themes. Each transcript underwent pair-comparison, then each group presented their own mapping in the group comparisons sessions and finally, the mapping for each group was drabbed based on factors that contribute to parents' perspective on pre-school ethos.

\section{Findings}

\section{Pre-school Setting: The Pre-school Routine and Cultural Elements}

The common routine activities in pre-school day consist of the arrival time, morning assembly, hand-kissing, the salaam, the Rukun Negara (Malaysia Principle) and Negaraku (Malaysia Anthem), outdoor activity, and table manners during meal time. The routine daily practices in the PERPADUAN Pre-school were acceptable to the multi-ethnic children.

The teacher in charge would stand at the school gate to greet the children and the parents as the children arrive. The teacher would greet the child with the salaam. The child, in turn, would answer the teacher with the prescribed answer and also shake the teacher's right hand with his or her own right hand and kiss the teacher's hand by bringing it to his or her nose. The child would then put away his or her things in the school building and join the other children playing. (Observation: Morning Session Episode [12 June 2018]). 
This hand-kissing ritual is an element of Malay culture as a sign of respect. The rule of Malay hierarchy is observed by the act of the children kissing the teacher's hand. This kind of ritual has become the regular basis for all children because it is acceptable to the other ethnic groups as part of showing respect to elders.

... The teacher led the assembly. She stood in front facing the children while the assistant teacher stood on the periphery of the children's group. ... followed next was a ritual of greetings. The teacher first greeted the children with the salaam, to which the children responded appropriately, (Observation: Morning Routine Episode [12 June 2018]).

The salaam is both the greeting and farewell ritual in Islam while "Vanakkam" (Tamil) and "Chao $a n$ " or "zao'an" (Mandarin) which mean "Good morning" have created a sense of understanding among all the ethnic groups. The salaam is both the greeting and farewell ritual in Islam. In this regard the school had managed to instil in the students an Islamic sociocultural practice in this otherwise daily routine.

Children learn to practice the dua, the school is attempting to instil this habit in children. We see that the Islamic rituals associated with eating had been consciously observed during the snack time. The children were gently reminded of their manners and of the appropriate hand to use when directly handling food.

Children are exposed to the teaching of moral and spiritual values. The teaching of spiritual and moral aspects contains components of Islamic Education for Muslim students and Moral Education for non-Muslim students. Islamic Education focuses on the delivery of knowledge, skills and appreciation of Islam. Despite developing children with good characteristics through preschool routines like "dua" and kissing hands, some of the findings evidently suggest that there are some lively 'sensitive issues'. Most of the issues commented on by the parents are related to the school's reluctance to act in a culturally sensitive way. Parent's view:

Let the children understand the three main ethnic cultures ...rather than Malay culture as it seems to be the case today...nurturing the children with three languages and different cultures should be the way to promote ethnic understanding. It does not show in school practices, does it? The school norms tend to practise the Muslim religious values [Malay] in everyday practice. But this is only my opinion. (Paragraph 47)

Mr Bo: 20 years ago, I didn't have any problem with other friends from different ethnic groups. Nowadays school practice is different, the practise elements of Islamic apply to all children at PERPADUAN Pre-school which look like an Islamisation process (Paragraph 144)

This parent is concerned that practising the elements of Muslim religion at pre-school contradicts what he gives his child at home. Some parents said that the pre-school practices seemed to disregard cultures other than Malay. They viewed that it is important for a multi-ethnic preschool to nurture children with the different cultures. These parents are concerned that practising elements of Islam at pre-school contradicted what they gave their children at home. We found that some parents were worried about the Islamisation of the PERPADUAN Pre-school. Some of the non-Malay parents are "scared and afraid" of the Muslim "dua" and the hand kissing. The teacher has discussed with the parents' committee members about the aims of "dua" and 
Vol. 10, No. 1, 2021, E-ISSN: 2226-6348 @ 2021 HRMARS

hand kissing, which are not to create Islamisation or a dominant culture. However, some of the reactions and reflections on the routines suggest that it creates prejudice and has developed fear among parents, especially the non-Malays. The school is attempting not to Islamise the culture, so not only is the teacher saying there is no Islamisation but there are practices which indicate it is not Islamisation nevertheless, the parents are still concerned.

\section{Discussion}

The results from the interviews, that practices apparently focused on particular ethnic groups may encourage prejudice and discourage integration. Too much attention paid to a particular group will inspire prejudice and fear among others when their own group continues to receive minimum attention. On most occasions, especially during the pre-school assembly and at the beginning of classroom teaching and learning, the teacher and children will first recite "dua" or blessing in Malay and a few Arabic words. Reciting "dua" is an act highly encouraged in Islam, regardless of time and place, but in PERPADUAN Pre-school this ritual is 'over emphasised' and regarded as 'compulsory', so that everybody must follow it regardless of their religion, even though the "dua" is recited in Malay. Some might think that this is an act of the Islamisation of pre-school and this might worry them. For this reason it is understandable that those parents have concerns over the Islamic practices, in this case the " $d u a$ ".

These practices in the PERPADUAN Pre-school concern the non-Malay parents and so this suggests the need to hold more discussion between parents and teacher to explain the policies and practices and overcome these fears. What this research has importantly done is give a voice to the non-Malay parents and allows them to express those fears which can hopefully inform future policy. We have signalled to the pre-school that this could be an issue because the practices are not understood by the parents in the way that the school intends, so the school and government need to find ways of explaining the policy and practices and so reassuring the nonMalay parents that this is not an attempt at Islamisation. Therefore, the pre-school ethos works in line with the behaviour accepted by the parents and community, and this is consistent with findings from Corsaro and Molinari (2000) on the types of priming events in the pre-school in which children participate and attend prospectively to on-going or anticipated in activities have changed their lives. They identify different types of priming events in pre-school and show how collective activities in these events affect the children's representations (p.16). We found that different types of priming events involving children's collective and practical activities with others in the pre-school setting such as seating formation, school routines and rituals, are crucial in priming children's behaviour.

This study is consistent with studies by Majzub (2006) who examined the way the pre-school space is constructed and used with reference to pedagogical materials. Materials are described as an element of the spatiality of pre-school, their meaning constructed from the interaction between physical and social forces, and which cultivated the children's aesthetic sense and selfconfidence. Materials in the pre-school space encourage the children's interactions. It depends on what way the pre-school materials and environment reflect children's backgrounds. This includes the design of the building, its location in the community, the people, materials, and furnishings within it. 


\section{Conclusion}

In conclusion, based on the findings, the practices of routine activities in pre-school setting is accepted the most importance part to develop children self-entity and norms. The impact of this research to theory gives a new input for teachers that the benefit of practices of routines activities to integrate values and norms of community in general, and value and niche of preschool. However, based on summary from the results and discussion, that practices apparently focused on particular ethnic groups may encourage prejudice and discourage integration. Too much attention paid to a particular group will inspire prejudice and fear among others when their own group continues to receive minimum attention.

\section{Acknowledgement}

This part of the research "Development of a comprehensive and integrated model of quality Malaysian early childhood care and education-project 3/TLAA: determining contributing factors of quality ecce" (2015-0024-106-04-3) is funded by the Ministry of Finance through the Malaysian Ministry of Education. Special appreciation is also dedicated to the National Child Development Research Centre, Universiti Pendidikan Sultan Idris, Malaysia for giving us the opportunity to carry out this research project.

\section{Corresponding Author}

Associate Prof. Dr. Nordin Mamat

Associate Professor Department of Early Childhood Education Faculty of Human Development Universiti Pendidikan Sultan Idris Perak Malaysia

Email: nordin@fpm.upsi.edu.my

\section{References}

Beaty, J. J. (2016). Skills for Preschool Teachers. United Kingdom: Pearson Education.

Beaty, J. J. (2014). Preschool Appropriate Practices: Environment, Curriculum, and Development. United States: Cengage Learning.

Bentley, F. D. (2012). Rights are the Words for Being Fair: Multicultural Practice in the Early Childhood Classroom. Early Childhood Education Journal. 40, 195-202.

Buchori, S., \& Dobinson, T. (2015). Diversity in teaching and learning: Practitioners' perspectives in a multicultural early childhood setting in Australia. Australasian Journal of Early Childhood, 40 (1) 71-79.

Corsaro, W. A. (2005). The sociology of childhood (2ed.). London: Sage Publications.

Gillen, J., \& Kucirkova, N. (2018) Percolating spaces: Creative ways of using digital technologies to connect young children's school and home lives. British Journal of Educational Technology 49(5) 834-846.

Hruska, C. A. (2017). Strategies for teacher learning and development over child-adult interactions in ECE settings. In Gunn, A.C \& Hruska, C.A. (Ed). Interactions in early childhood education: Recent research and emergent concepts. Singapore: Springer.

Luen, C. L., Mamat, N., Radzi, N. M. M., \& Yassin, S. M. (2017). Observation Instrument to Evaluate Early Childhood Educator's Teaching Strategies using Creative Arts. International Journal of Academic Research in Business and Social Sciences. 7(4) 870-880. 
Majzub, R. M. (2006). The inculcation of National Integration through pre-school education: A case of Tabika Perpaduan Negara. In Z. Hassan, A. L. Samian \& A. D. Silong (Eds.), Reading on ethnic relations in a multicultural society. Serdang: UPM Press.

Ministry of Education Malaysia. (2017). Kurikulum Standard Prasekolah Kebangsaan.

Mamat, N., Radzi, N. M. M., Luen, L. C., \& Yassin, S. M. (2017). The Selection of Meaningful Approach to Assess Children's Science Process Skills. International Journal of Academic Research in Business and Social Sciences. 7(4), 860-869. DOI:10.6007/IJARBSS/v7-i4/2897

Mamat, N., Luen, L. C., Radzi, N. M. M., Yassin, S. M., \& Yusoff, S. I. M. (2018). Reliability, Validity and Fairness of Interviews for Teaching and Learning Project in Quality Early Childhood Care and Education: Preliminary Study. International Journal of Academic Research in Business and Social Sciences. 8(6), 1283-1292. http://dx.doi.org/10.6007/IJARBSS/v8i6/4516

Mamat, N., Luen, L. C., Mustapha, M. C., Razalli, A. R., \& Hashim, A. T. M. (2019). The Quality of PERPADUAN Pre-school Environment and Human Resources: Teachers' Satisfaction on their Career Development. International Journal of Academic Research in Business and Social Sciences. 9(5), 882-897. http://dx.doi.org/10.6007/IJARBSS/v9-i5/6015 